\title{
Company aims to beat NIH human genome efforts
}

[WASHINGTON] A private initiative has been launched in the United States to use state-ofthe-art technology to sequence the entire human genome within the next three years - four years earlier than the target of efforts being run by the federal government.

The Applied Biosciences Division of Perkin-Elmer, based in Norwich, Connecticut, is teaming up with J. Craig Venter, president of The Institute for Genomic Research

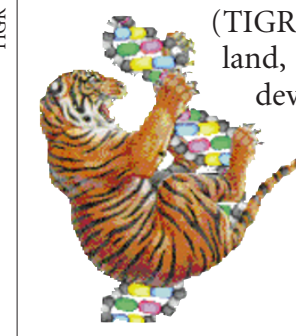

TIGR's aggressive approach looks set to pay off.

\section{Perkin-Elmer, known}

as the 3700 DNA Analyzer. This combines increased sensitivity and automation to lower dramatically the cost and raise the rate of sequencing.

Venter says the cost will be reduced to $\$ 0.10$ per base pair (the government's effort costs about \$0.50). This would put the overall price of sequencing the human genome at between $\$ 100$ million and $\$ 300$ million far below the $\$ 3$ billion government price.

The new company, to be located in Rockville, will house 200 to 230 of the new machines, which will be in operation by early 1999 , say the executives. They say the operation will outstrip the capacity of all sequencing centres in the world combined, and that the company will act as a 'beta test' site for the new instrument.

Venter will leave TIGR to become president of the company, which is as yet unnamed. Its chairman will be Tony White, Perkin-Elmer's chairman, president and chief executive officer. Perkin-Elmer will own 80 per cent of the company, Venter and others the rest.

The company also intends to build an information-rich database adding information to raw sequence data which analyses it and thus makes it more valuable to scientists, companies and institutions. The goal, say the executives, is that the database should become "the definitive source of genomic and associated medical information".

It will, for example, include all-important data on common variations in DNA called polymorphisms. Ultimately, the principals say, the project will lay the groundwork for new diagnostics and therapies tailor-made to the needs of individuals.
Venter says that the company plans to make the database available to researchers for a reasonable fee, and to limit its patent claims to between 100 and 300 therapeutically important genes. The company will make the raw data themselves publicly available without charge. But the value, Venter says, will be in the database. "This is going to be an extremely high value database and we expect extremely wide subscriptions."

Some scientists have expressed fears that the company could at any time make the terms of access more onerous. Venter insists, however, that the data would not be "held hostage", saying that such a move would be "morally wrong".

The announcement was greeted cautiously but positively by the leaders of the government's Human Genome Project, who held a press conference with Venter and Michael Hunkapiller, the president of Perkin-Elmer's Applied Biosciences Division, on Monday (11 May) to respond to the news.

"We're hearing the discussion of a plan and not proof of the principle," said Harold Varmus, the director of the National Institutes of Health (NIH). He added that federal sequencing efforts at some dozen sequencing centres will continue "unabated for the moment". The NIH is the major federal player in sequencing the genome, with the Department of Energy playing a smaller role.

Francis Collins, the director of the National Human Genome Research Institute at NIH, called the venture "significant" but warned that its ability to meet its ambitious timetable remains to be demonstrated. It would be "vastly premature", he said, to alter current federal efforts in response to the news.

Ari Patrinos, the associate director of the Office of Biological and Environmental Research at the energy department, said the effort would "raise the bar" for government scientists, which would make them "even more productive".

The notion that a company could use new technology rapidly to outstrip the government effort - which has sequenced just 3 per cent of the genome so far - has put the government's role into a dramatically new light. It raises the question of whether Congress would continue to support the government project at the same level when a simultaneous effort was being carried out speedily with private money.

But Varmus warned that the proposed venture "will be one component factored into a very complex research agenda". Collins said that the plan to accelerate genome sequencing makes legislating against employment and insurance discrimination all the more urgent.
MeredithWadman

\section{Australia's research budget to remain flat for three years}

[CANBERRA] The Australian government has failed to give higher priority to funding research, despite heightened lobbying by scientists and reforms of policy advisory mechanisms - including moving the science portfolio into the cabinet.

Budget details released this week reveal that public funding for the category of 'general research' will remain virtually flat over the next three years at $\mathbf{A} \$ 1,255$ million (US\$797 million) in 1998-99, falling to $\$ 1,247$ million in 2001-02.

The third and final budget of the Coalition government delivers increases for medical research and marine science, and promises funding for a controversial new research reactor. But these have been offset by cuts elsewhere, in particular to the Australian Research Council, which provides support primarily for university research, and whose budget will fall from $\mathrm{A} \$ 445$ million in 1998-99 to A \$390 million three years later.

Treasurer Peter Costello promised "wonderful opportunities" ahead as a result of the government's economic policies, which have moved the budget from deficit into surplus. But he gave no indication of any change of heart towards the funding of research as part of such prosperity, and his speech did not mention universities, science or technology.

Research gained one mention - an increase for medical research. Following intense lobbying by the biomedical research community, the National Health and Medical Research Council will receive A\$194 million in the coming year. Although its funding will fall to A $\$ 179.5$ million in 1999-2000, health minister Michael Wooldridge says this will be $\mathbf{A} \$ 50$ million more than last year's forward estimates.

In his first year fully responsible for science, John Moore, Minister for Industry, Science and Tourism, secured some modest increases. The START programme of grants through the Industrial Research and Development Board spent A\$82 million in the financial year that is just finishing, A \$49 million less than its budgetary allocation. But a spokesman for Moore says the government's commitment to spending $\$ 1$ billion over four years on START will be "maintained".

The Australian Institute of Marine Science, based in Townsville, Queensland, will benefit from an extra A $\$ 11.3$ million over four years to replace one ageing research vessel, refurbish another and upgrade laboratory and other facilities. The institute's director, Russell Reichelt, greeted the funding as a "welcome boost to marine science".

But universities have received no relief for the cuts made to operational funds during the past two years.

Peter Pockley 